\title{
STUDI KELAYAKAN PENGEMBANGAN BISNIS PADA PT DAGANG JAYA JAKARTA
}

\author{
Santi Nurjanah \\ PT Dagang Jaya Jakarta \\ Jln. Seni Budaya Raya, No.10, Jelambar Baru, Jakarta Barat 11460 \\ potter_251289@yahoo.com
}

\begin{abstract}
The purpose of the study is to determine the feasibility of the development of the business conducted by PT Dagang Jaya. Research method used is based on the analysis of aspects of business feasibility study, the aspects of Finance, Markets and Marketing, Management and HR, Legal aspects, Engineering and Operations, EIA, and the Economic and Social aspects. The results of the analysis of each aspect showed positive results stating that the Business Development conducted by PT Dagang Jaya feasible to run. Conclusions from this research is the development of the business conducted by PT Dagang Jaya feasible to run one way to choose business development is to increase the number and variety of products distributed by the company.
\end{abstract}

Keywords: feasibility study, business development

\begin{abstract}
ABSTRAK
Tujuan penelitian ini adalah untuk mengetahui kelayakan pengembangan bisnis yang dilakukan oleh PT Dagang Jaya. Metode penelitan yang digunakan adalah analisis berdasarkan aspek-aspek studi kelayakan bisnis, yaitu aspek Keuangan, Pasar dan Pemasaran, Management dan SDM, aspek Hukum, Teknik dan Operasional, AMDAL, serta aspek Ekonomi dan Sosial. Hasil analisis masing-masing aspek menunjukan hasil yang positif yang menyatakan bahwa Pengembangan Bisnis yang dilakukan oleh PT Dagang Jaya layak untuk dijalankan. Simpulan dari penelitian ini adalah pengembangan bisnis yang dilakukan oleh PT Dagang Jaya layak untuk dijalankan salah satu cara pengembangan bisnis yang dapat dipilih adalah dengan menambah jumlah dan variasi produk yang didistribusikan oleh perusahaan.
\end{abstract}

Kata kunci: studi kelayakan, pengembangan bisnis 


\section{PENDAHULUAN}

Industri pendistribusian produk minuman kopi instan di Indonesia saat ini menjadi salah satu industri yang memiliki daya tarik tersendiri. Industri ini terus bertumbuh setiap tahunnya, data BPS menyatakan bahwa pada tahun 2011 terjadi peningkatan import-export pada industri non migas sebesar 30,7\% dari tahun sebelumnya dan produk minuman kopi instan termasuk dalam peningkatan tersebut. PT Dagang Jaya merupakan salah satu pelaku dalam bisnis distribusi minuman kopi instan ini. Produk minuman instan yang didistribusikan oleh PT Dagang Jaya adalah produk minuman instan CheckHup, merk dagang CheckHup ini membuat beberapa jenis produk yaitu diantaranya adalah White Coffee, Teh Tarik, Hot Chocolate, dan Gula.

Penjualan produk minuman instan CheckHup yang didistribusikan oleh PT Dagang Jaya setiap tahunnya mengalami peningkatan yang cukup signifikan. Pada tahun 2012 terjadi peningkatan penjualan sebesar 9,6\% dari tahun sebelumnya. Berdasarkan dari beberapa hal tersebut maka manajemen PT Dagang Jaya ingin melakukan pengembangan bisnis distribusi produk minuman ini. Keefektifan dan efisiensi manajemen perusahaan juga menjadi salah satu pertimbangan perusahaan dalam mengembangkan bisnis distribusi produk minuman ini.

Penelitian ini dilakukan untuk mendapatkan jawaban dari pertanyaan (a) Bagaimana analisis kelayakan bisnis distribusi produk minuman CheckHup oleh PT Dagang Jaya ditinjau dari aspek pasar dan pemasaran, aspek manajemen dan SDM, aspek teknis dan teknologi, aspek lingkungan, aspek hukum, aspek ekonomi dan sosial? (b) Berdasarkan aspek keuangan bagaimana dengan kelayakan pengembangan bisnis bila dilihat dari Payback Period (PP), Net Present Value (NPV), Internal Rate of Return (IRR), dan Profitability Index (PI)? (c) Bagaimana analisis sensitivitas bisnis distribusi produk minuman CheckHup yang dilakukan oleh PT Dagang Jaya?.

Tujuan dari penelitian ini adalah untuk mengetahui kelayakan bisnis distribusi produk minuman ChekHup yang ditinjau dari aspek-aspek studi kelayakan bisnis, dan mengetahui bagaimana perhitungan PP, NPV, IRR, dan PI pada bisnis ini. Selain itu tujuan dari penelitian ini juga untuk mengetahui bagaimana analisis sentitivitas dari bisnis distribusi ini.

Manfaat penelitian ini adalah untuk mengetahui bagaimana kelayakan bisnis distribusi produk minuman CheckHup pada PT Dagang Jaya berdasarkan pada aspek-aspek studi kelayakan bisnis.

\section{Tinjauan Pustaka}

\section{Studi Kelayakan}

Menurut Kasmir dan Jakfar (2012) studi kelayakan bisnis adalah suatu kegiatan yang mempelajari secara mendalam tentang suatu kegiatan atau usaha yang akan dijalankan, untuk menentukan layak atau tidaknya suatu bisnis dijalankan. Menurut Umar (2005) studi kelayakan bisnis merupakan penelitian terhadap rencana bisnis yang tidak hanya menganalisis layak atau tidak layak bisnis dibangun, tetapi juga saat dioperasionalkan secara rutin dalam rangka pencapaian keuntungan yang maksimal untuk waktu yang tidak ditentukan, misalnya rencana peluncuran produk baru. Suliyanto (2010) menyatakan beberapa perbedaan studi kelayakan bisnis dengan rencana bisnis (businessplan) berdasarkan sumber data penelitian, penyusun penelitian, tujuan dari studi kelayakan dan rencana bisnis, waktu penelitian, dan biaya yang dibutuhkan oleh masing-masing. 


\section{Aspek Pasar dan Aspek Pemasaran}

Dalam sebuah studi kelayakan bisnis aspek pasar dan pemasaran merupakan salah satu aspek yang paling penting, karena aspek pasar dan pemasaran menentukan hidup atau tidaknya sebuah perusahaan di dalam industri. Menurut Thamrin dan Tantri (2012) pemasaran adalah suatu sistem total dari kegiatan bisnis yang dirancang untuk merencanakan, menentukan harga, mempromosikan dan mendistribusikan barang-barang yang dapat memuaskan keinginan dan jasa baik kepada konsumen saat ini maupun konsumen potensial.

\section{Aspek Manajemen dan Sumber Daya Manusia}

Dalam menganalisis studi kelayakan bisnis aspek manajemen dan SDM penting dianalisis karena dalam menjalankan sebuah organisasi, manajemen satu dengan yang lainnya memiliki keterkaitan pekerjaan. Suatu organisasi selalu diibaratkan dengan sebuah tubuh, apabila akan melakukan sebuah perubahaan namun sebagian dari organ tubuh tidak siap untuk menerima perubahan tersebut maka perubahan yang telah direncanakan tidak akan dapat dijalankan.

\section{Aspek Teknis dan Operasional}

Langkah selanjutnya dalam penentuan kelayakan suatu rencana bisnis adalah menganalisis aspek teknis dan teknologi. Evaluasi aspek teknis ini mempelajari kebutuhan-kebutuhan teknis bisnis, seperti penentuan kapasitas produksi, jenis teknologi yang dipakai, pemakaian peralatan dan mesin, lokasi bisnis dan letak perusahaan yang paling menguntungkan. Lalu dari kesimpulannya dapat dibuat rencana jumlah biaya pengadaan harta tetapnya.

\section{Aspek AMDAL (Analisa Dampak Lingkungan Hidup)}

Pertumbuhan dan pekembangan perusahaan berpengaruh terhadap lingkungan sekitar apakah membawa dampak negatif atau positif terhadap masyarakat sekitar atau sebaliknya apakah masyarakat sekitar membawa dampak positif atau negative terhadap perusahaan. Analisia yang dilakukan terhadap aspek ini bermanfaat untuk mengindentifikasi kelayakan bisnis yang dijalankan sesuai dengan standar lingkungan hidup yang ada. Salah satu media dari aspek ini adalah AMDAL (Analisis Dampak Lingkungan) yang sedang dan telah dikembangkan di beberapa Negara maju dengan nama Environmental Impact Analysis atau Envirinmental Impact Assessment (EIA).

\section{Aspek Hukum}

Berdasarkan pendapat Husnan dan Suwarsono (2007) aspek hukum dalam studi kelayakan menganalisis tentang: (1) Bentuk badan usaha yang akan dipergunakan. (2) Jaminan-jaminan yang bisa disediakan kalau akan menggunakan sumber dana berupa pinjaman. Berbagai akta, sertifikat, izin yang diperlukan dan sebagainya

\section{Aspek Ekonomi dan Sosial}

Kasmir dan Jafar (2012) menyebutkan beberapa dampak yang akan mempengaruhi berbagai pihak tersebut, baik itu positif maupun negatif sebagai berikut: (1) Bagi masyarakat dampak positif yang diperoleh dari sebuah bisnis ditinjau dari aspek ekonomi adalah peluang untuk meningkatkan pendapatan. Sedangkan bagi pemerintah dampak positif yang diperoleh adalah memberikan pemasukan berupa pendapatan. Selain itu dampak positif lainnya adalah pengaturan dan pengelolaan SDA yang belum terjamah. (2) Dampak negatif sebuah bisnis ditinjau dari aspek ekonomi adalah eksplorasi SDA yang berlebihan, masuknya pekerja dari luar daerah sehingga mengurangi peluang bagi masyarakat sekitarnya. (3) Dampak positif sebuah bisnis ditinjau dari aspek sosial dari tinjauan masyarakat secara umum adalah tersedia sarana dan prasarana yang dibutuhkan seperti pembangunan 
jalan, jembatan, listrik, dan sarana lainnya. (4) Dampak negatif sebuah bisnis ditinjau dari aspek sosial dari tinjauan pemerintah adalah perubahan demografi di suatu wilayah, perubahan budaya, dan kesehatan masyarakat.

Irham Fahmi (2011) menyatakan bahwa tanggungjawab sosial (social responsibility) adalah kewajiban manajemen untuk membuat pilihan dan mengambil tindakan yang berperan dalam mewujudkan kesejahteraan dan masyarakat.

\section{Aspek Keuangan}

Kismono (2011) menyatakan ada tiga keputusan penting dalam manajemen keuangan sebuah perusahaan, yaitu: (1) Memperoleh dana (keputusan pendanaan). (2) Penggunaan dana (keputusan investasi). (3) Pembagian laba (kebijakan dividen)

Kasmir dan Jafar (2012) menyebutkan bahwa secara keseluruhan penilaian aspek keuangan meliputi: (1) Sumber-sumber dana yang akan diperoleh. (2) Kebutuhan biaya investasi. (3) Estimasi pendapatan dan biaya investasi selama beberapa periode termasuk jenis-jenis dan jumlah biaya yang dikeluarkan selama umur investasi. (4) Proyeksi neraca dan laporan laba/rugi untuk beberapa periode ke depan. (5) Kriteria penilaian investasi. (6) Rasio keuangan yang digunakan untuk menilai kemampuan perusahaan.

\section{METODE}

Penelitian dilakukan di PT Dagang Jaya dengan cara melakukan wawancara, observasi dan pengolahan data penjualan perusahaan. Tabel 1 merupakan kriteria optimasi yang digunakan dalam penelitian ini.

Tabel 1 Kriteria Optimasi Studi Kelayakan Bisnis

\begin{tabular}{|c|c|}
\hline Aspek Studi Kelayakan & Kriteria \\
\hline Aspek Keuangan & $\begin{array}{cl}\text { Kriteria yang digunakan dalam aspek ini adalah: } \\
- & \text { Perhitungan PP } \\
- & \text { Perhitungan NPV } \\
\text { - } & \text { Perhitungan IRR } \\
\text { - } & \text { Perhitungan PI } \\
\end{array}$ \\
\hline Aspek Pasar dan Pemasaran & $\begin{array}{cl}\text { Kriteria yang mencakup aspek pasar dan pemasaran ini meliputi: } \\
\text { - } & \text { Data permintaan pasar } \\
- & \text { Jumlah penawaran } \\
\text { - } & \text { Proyeksi penjualan } \\
\text { - } & \text { Analisis pesaing } \\
- & \text { Bauran pemasaran } \\
\end{array}$ \\
\hline Aspek Manajemen dan SDM & $\begin{array}{cl}\text { Kriteria utama didalam aspek ini adalah } \\
-\quad & \text { struktur organisasi } \\
- & \text { SDM didalam perusahaan }\end{array}$ \\
\hline Aspek Hukum & 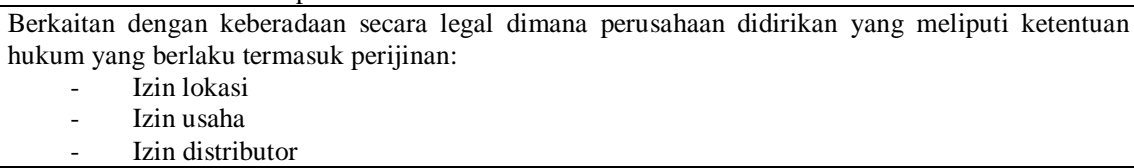 \\
\hline AMDAL & $\begin{array}{l}\text { Aspek ini merupakan suatu analisa dampak pada lingkungan hidup (alam), dimana perusahaan } \\
\text { merupakan salah satu penyumbang produk yang dapat mengotori lingkungan atau tidak. }\end{array}$ \\
\hline Aspek Teknis dan Operasional & $\begin{array}{l}\text { Aspek ini meneliti mengenai teknis atau cara-cara yang dilakukan oleh perusahaan dalam } \\
\text { pendistribusian Produk ChekHup dan bagaimana sistem operasional pendistribusian produk tersebut } \\
\text { oleh PT Dagang Jaya. }\end{array}$ \\
\hline Aspek Ekonomi dan Sosial & $\begin{aligned} \text { Dalam aspek ini dijelaskan kriteria yang meliputinya yaitu } \\
\text { - } \quad \text { Dampak ekonomi } \\
\text { - } \quad \text { Dampak sosial }\end{aligned}$ \\
\hline
\end{tabular}

Sumber: Pengolahan data 


\title{
HASIL DAN PEMBAHASAN
}

Setelah data dan hasil wawancara diperoleh dan kemudian dianalisis berdasarkan pada kriteria optimasi studi kelayakan bisnis, maka didapat hasil sebagai berikut:

Tabel 2 Hasil Analisis Kriteria Optimasi

\begin{tabular}{|c|c|c|}
\hline No. & Aspek Studi Kelayakan & Hasil \\
\hline 1 & Aspek Pasar dan Pemasaran & $\begin{array}{l}\text { Analisa yang dilakukan di dalam aspek pasar dan pemasaran PT Dagang Jaya } \\
\text { menunjukan bahwa penjualan produk minuman instan CheckHup setiap tahunnya } \\
\text { mengalami peningkatan permintaan, dengan perkiraan peningkatan rata-rata permintaan } \\
\text { sebesar } 7-8 \% \text { per tahun maka menurut aspek ini pengembangan bisnis layak untuk } \\
\text { dilakukan oleh PT Dagang Jaya. }\end{array}$ \\
\hline 2 & $\begin{array}{l}\text { Aspek Manajemen dan Sumber Daya } \\
\text { Manusia }\end{array}$ & $\begin{array}{l}\text { Analisa yang dilakukan dalam aspek ini menghasilkan penjelasan mengenai jenis } \\
\text { pekerjaan, deskripsi pekerjaan, dan struktur organisasi pada karyawan yang sudah sesuai } \\
\text { dengan apa yang dibutuhkan PT Dagang Jaya dalam menjalankan perusahaannya. Pada } \\
\text { aspek ini juga perusahaan telah menetapkan manajemen dan sumber daya manusia yang } \\
\text { sesuai yang dapat membantu perusahaan dalam melakukan pengembangan bisnis, maka } \\
\text { pengembangan bisnis layak untuk dilakukan. }\end{array}$ \\
\hline 3 & Aspek Teknis dan Operasional & $\begin{array}{l}\text { Analisa yang dilakukan pada aspek ini menghasilakn penjabaran bagaimana proses kerja } \\
\text { di dalam perusahaan, bagaimana proses distribusi barang dagang. Dengan menambah } \\
\text { jenis produk CheckHup PT Dagang Jaya dapat mengembangkan keagenan penjualan } \\
\text { produk ini semakin besar lagi, maka pengembangan bisnis yang akan dilakukan oleh } \\
\text { perusahaan layak untuk dilakukan. }\end{array}$ \\
\hline 4 & Aspek AMDAL & $\begin{array}{l}\text { Hasil analisis terhadap aspek AMDAL ini menunjukan bahwa produk perusahaan tidak } \\
\text { merusak lingkungan hidup, maka pengembangan layak untuk dilakukan. }\end{array}$ \\
\hline 5 & Aspek Hukum & $\begin{array}{l}\text { Semua ketentuan hukum yang harus dilaksanakan oleh PT Dagang Jaya telah dilakukan, } \\
\text { seluruh persyaratan dan berkas-berkas perusahaan telah lengkap. Maka pengembangan } \\
\text { bisnis layak untuk dilakukan. }\end{array}$ \\
\hline 6 & Aspek Ekonomi dan Keuangan & $\begin{array}{l}\text { Dalam menganalisa aspek ini PT Dagang Jaya menjalankan perusahaan semata-mata } \\
\text { bukan hanya ingin mencari keuntungan yang besar saja, di dalam perlaksanaanya } \\
\text { perusahaan memiliki tanggung jawab sosial kepada para pegawai perusahaan serta } \\
\text { kepada lingkungan sekitar perusahaan. Dengan berjalannya perusahaan maka PT Dagang } \\
\text { Jaya juga turun membantu memberi penghasilan kepada } 56 \text { orang karyawan dan pekerja } \\
\text { yang ada di perusahaan. }\end{array}$ \\
\hline 7 & Aspek Keuangan & $\begin{array}{l}\text { Tiga skenario yang digunakan dalam perhitungan aspek keuangan menunjukan bahwa } \\
\text { pengembangan bisnis yang akan dilakukan oleh perusahaan layak. Di dapat bahwa } \\
\text { dengan melakukan penambahan produk CheckHup maka laba perusahaan terus } \\
\text { bertambah dan setiap tahunnya mengalami peningkatan. }\end{array}$ \\
\hline
\end{tabular}

Sumber: pengolahan data

Analisis pada aspek keuangan perusahaan dibuat menjadi tiga skenario yaitu skenario moderat, optimis, dan pesimi. Pembahasan dari masing-masing skenario tersebut dibahas sebagai berikut.

\section{Skenario Moderat}

Pada skenario ini diasumsikan bahwa pertumbuhan pasar (market growth) perusahaan pada penjualan produk minuman CheckHup adalah sebesar 25\%. Dengan demikian maka perhitungan PP, NPV, IRR, dan PI perusahaan sebagai berikut:

\author{
Payback Period \\ $\mathrm{n}+(\mathrm{a}-\mathrm{b}) /(\mathrm{c}-\mathrm{b}) \mathrm{x} 1$ tahun \\ $2+(3.112 .060 .000-1.062 .026 .421) \times 1$ tahun \\ (1.767.211.72-1.062.026.421) \\ $=4$ tahun
}


Simpulan yang diperoleh dari perhitungan ini adalah bahwa modal bisnis akan kembali dalam empat tahun. Karena payback period lebih kecil dari umur ekonomis aktiva perusahaan, investasi dinyatakan layak untuk dijalankan.

Tabel 3 Net Present Value Skenario Moderat (dalam rupiah)

\begin{tabular}{|c|c|c|c|}
\hline \multicolumn{4}{|c|}{ NPV } \\
\hline periode & Factor Diskonto OCF (10\%) & Cash Flow & PV \\
\hline 0 & 1 & 3.112 .060 .000 & 3.112 .060 .000 \\
\hline 1 & 0.906600269 & 576.731 .763 & 522.865 .171 \\
\hline 2 & 0.821924048 & 780.914 .321 & 641.852 .260 \\
\hline 3 & 0.745156564 & 884.266 .503 & 658.916 .989 \\
\hline 4 & 0.675559141 & 1.079 .504 .978 & 729.269 .456 \\
\hline \multirow[t]{3}{*}{5} & 0.6124621 & 1.184 .105 .853 & 725.219 .957 \\
\hline & & & 6.390 .183 .833 \\
\hline & $V \mathbf{P}$ & & 3.278.123.833 \\
\hline
\end{tabular}

$\sum \underline{\mathrm{Rt}}$

$(1+\mathrm{i})^{\mathrm{t}}$

$\frac{576.731 .763}{(1+0.10 \%)^{1}}+\quad \frac{780.914 .321}{(1+0.10 \%)^{2}}+\quad \frac{884.266 .503}{(1+0.10 \%)^{3}}+\frac{\frac{1.079 .504 .978}{(1+0.10 \%)^{4}}}{+}$

$\underline{1.184 .105 .853}$

$(1+0.10 \%)^{5}$

$=3.278 .123 .833$

Simpulan yang didapat dari perhitungan ini adalah bahwa NPV sebesar Rp3.278.123.833 yang menunjukan hasil positif. Berarti, investasi pengembangan bisnis dengan menambah jenis produk CheckHup ini dinyatakan layak untuk dijalankan oleh PT Dagang Jaya.

Tabel 4 Internal Rate of Return Skenario Moderat (IRR) (dalam rupiah)

\begin{tabular}{cl}
\multicolumn{1}{l}{ IRR } & \\
\hline Investasi & $(3.112 .060 .000)$ \\
OCF 2013 & 576.731 .763 \\
OCF 2014 & 780.914 .321 \\
OCF 2015 & 884.266 .503 \\
OCF 2016 & 1.079 .504 .978 \\
OCF 2017 & 1.184 .105 .853 \\
\hline IRR & $\mathbf{1 2 \%}$ \\
\hline
\end{tabular}

Sumber: pengolahan data

Simpulan yang didapat dari perhitungan ini adalah hasil IRR lebih besar dari COC maka investasi dinyatakan layak untuk dijalankan.

\section{Profitability Index (PI) \\ NPV/Investasi \\ 3.278.123.833 \\ 3.112 .060 .000 \\ $=1.06$}

Simpulan yang didapat dari perhitungan ini adalah hasil PI lebih besar dari 0 maka investasi untuk pengembangan bisnis melalui penambahan jenis produk minuman instan CheckHup dinyatakan layak. 


\section{Skenario Optimis}

Pada skenario ini diasumsikan bahwa pertumbuhan pasar (market growth) perusahaan pada penjualan produk minuman CheckHup adalah sebesar 40\%. Dengan demikian maka perhitungan PP, NPV, IRR, dan PI perusahaan sebagai berikut:

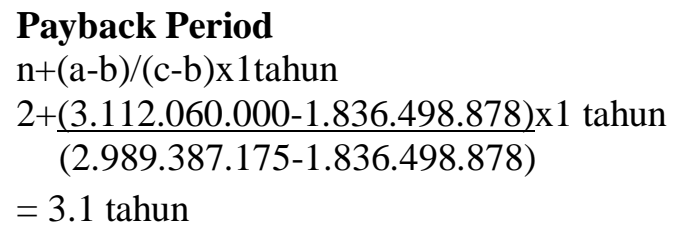

Simpulan yang didapat dari perhitungan ini adalah bahwa modal bisnis akan kembali dalam 3 tahun 1 bulan 2 hari. Karena payback period lebih kecil dari umur ekonomis aktiva perusahaan, maka investasi dinyatakan layak untuk dijalankan.

Tabel 5Net Present Value (NPV)Skenario Optimis (dalam rupiah)

\begin{tabular}{|c|c|c|c|}
\hline \multicolumn{4}{|c|}{ NPV } \\
\hline periode & Factor Diskonto OCF (10\%) & Cash Flow & PV \\
\hline 0 & 1 & 3.047 .760 .000 & 3.047 .760 .000 \\
\hline 1 & 0.907850126 & 806.448 .206 & 732.134 .106 \\
\hline 2 & 0.824191852 & 1.030 .050 .672 & 848.959 .370 \\
\hline 3 & 0.748242677 & 1.152 .888 .298 & 862.640 .226 \\
\hline 4 & 0.679292208 & 1.079 .504 .978 & 733.299 .320 \\
\hline \multirow[t]{3}{*}{5} & 0.616695517 & 1.184 .105 .853 & 730.232 .771 \\
\hline & & & 6.955 .025 .793 \\
\hline & JVP & & 3.907.265.793 \\
\hline
\end{tabular}

$\sum \underline{\mathrm{Rt}}$

$$
\sum_{(1+\mathrm{i})^{\mathrm{t}}}
$$

$\underline{860448206}+$

$(1+0.10 \%)^{1}$

$$
\frac{1.030 .050 .671 .71}{(1+0.10 \%)^{2}}+
$$$$
1.152 .888 .297 .53+
$$$$
(1+0.10 \%)^{3}
$$

$1.079 .504 .977 .75+$

$\underline{1.184 .105 .852 .80}$

$(1+0.10 \%)^{5}$

$=3.907 .265 .793$

$(1+0.10 \%)^{4}$

Simpulan yang didapat dari perhitungan ini adalah bahwa NPV sebesar Rp3.907.265.793 yang menunjukan hasil positif. Berarti, investasi ini dinyatakan layak untuk dijalankan oleh perusahaan.

Tabel 6 Internal Rate of ReturnSkenario Optimis (IRR) (dalam rupiah)

\begin{tabular}{lc}
\hline IRR & \\
\hline Investasi & $(3.112 .060 .000)$ \\
2013 & 806.448 .206 \\
2014 & 1.030 .050 .672 \\
2015 & 1.152 .888 .298 \\
2016 & 1.079 .504 .978 \\
2017 & 1.184 .105 .853 \\
\hline IRR & $\mathbf{2 0 \%}$ \\
\hline \multicolumn{2}{c}{ Sumber: pengolahan data }
\end{tabular}


Simpulan yang didapat dari perhitungan ini adalah hasil IRR lebih besar dari COC, maka investasi dinyatakan layak untuk dijalankan.

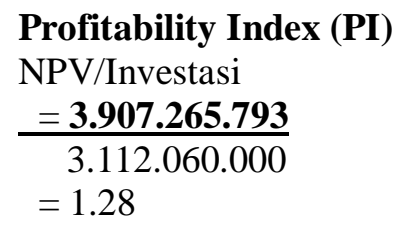

Simpulan yang didapat dari perhitungan ini adalah hasil PI lebih besar dari 0 maka investasi pengembangan bisnis pada PT Dagang Jaya dinyatakan layak untuk dijalankan.

\section{Skenario Pesimis}

Pada skenario ini diasumsikan bahwa pertumbuhan pasar (market growth) perusahaan pada penjualan produk minuman CheckHup adalah sebesar $15 \%$. Dengan demikian maka perhitungan PP, NPV, IRR, dan PI perusahaan sebagai berikut:

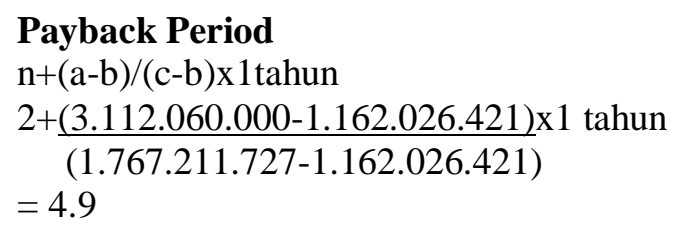

Simpulan yang dari perhitungan ini adalah bahwa modal bisnis akan kembali dalam 4 tahun 10 bulan. Karena payback period lebih kecil dari umur ekonomis aktiva perusahaan, maka investasi dinyatakan layak untuk dijalankan.

Tabel 7 Net Present Value (NPV) Skenario Pesimis (dalam rupiah)

\begin{tabular}{cccr}
\hline \multicolumn{5}{c}{ NPV } \\
\hline periode & Factor Diskonto OCF (10\%) & Cash Flow & \multicolumn{1}{c}{ PV } \\
\hline 0 & 1 & 3.047 .760 .000 & 3.047 .760 .000 \\
\hline 1 & 0.907850126 & 447.203 .000 & 405.993 .300 \\
\hline 2 & 0.824191852 & 614.823 .421 & 506.732 .454 \\
\hline 3 & 0.748242677 & 705.185 .306 & 527.649 .741 \\
\hline 4 & 0.679292208 & 1.079 .504 .978 & 733.299 .320 \\
\hline 5 & 0.616695517 & 1.184 .105 .853 & 730.232 .771 \\
\hline & & & 5.951 .667 .586 \\
\hline & NVP & & $\mathbf{2 . 9 0 3 . 9 0 7 . 5 8 6}$ \\
\hline & Sumber: pengolahan data &
\end{tabular}

$\sum \underline{\mathrm{Rt}}$

$(1+i)^{t}$

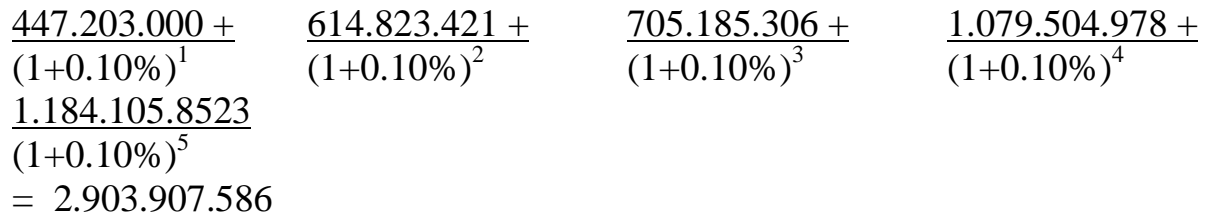


Simpulan yang didapat dari perhitungan ini adalah bahwa NPV sebesar Rp2.903.907.586 yang menunjukan hasil positif. Berarti, investasi pengembangan bisnis melalui penambahan jumlah produk ini dinyatakan layak untuk dijalankan oleh perusahaan.

Tabel 8 Internal Rate of Return (IRR) Skenario Pesimis (dalam rupiah)

\begin{tabular}{lr}
\hline IRR & \\
\hline Investasi & $(3.112 .060 .000)$ \\
OCF 2013 & 447.203 .000 \\
OCF 2014 & 614.823 .421 \\
OCF 2015 & 705.185 .306 \\
OCF 2016 & 1.079 .504 .978 \\
OCF 2017 & 1.184 .105 .853 \\
\hline IRR & \multicolumn{1}{c}{$\mathbf{9 \%}$} \\
\hline \multicolumn{2}{c}{ Sumber: pengolahan data }
\end{tabular}

Simpulan yang didapat dari perhitungan sebelumnya adalah hasil IRR lebih besar dari COC maka investasi dinyatakan layak untuk dijalankan.

$$
\begin{aligned}
& \text { Profitability Index (PI) } \\
& \text { NPV/Investasi } \\
& =\frac{2.903 .907 .586}{3.112 .060 .000} \\
& =0.95
\end{aligned}
$$

Simpulan yang didapat dari perhitungan ini adalah hasil PI dengan pembulatan sama dengan 1, maka proyek layak untuk dijalankan.

\section{SIMPULAN}

Dari hasil analisis seluruh aspek studi kelayakan bisnis maka diperoleh hasil bahwa pengembangan bisnis yang dilakukan oleh PT Dagang Jaya adalah layak untuk dilakukan. Pengembangan bisnis dilakukan dengan salah satu cara yaitu menambah jumlah produk dan menambah jenis produk minuman CheckHup tersebut.

\section{DAFTAR PUSTAKA}

Fahmi, I. (2011). Manajemen: Teori, Kasus, dan Solusi. Edisi 1. Bandung: Alfabet.

Husnan, S., Suwarsono. (2007). Study Kelayakan Proyek. Yogyakarta: Penerbit UPP-AMP YKPN.

Kasmir, Jakfar. (2012). Studi Kelayakan Bisnis. Edisi revisi. Jakarta: Kencana.

Kismono, G. (2011). Pengantar Bisnis. Edisi-2. Yogyakarta: BPFE.

Suliyanto. (2010). Studi Kelayakan Bisnis Pendekatan Praktis. Yogyakarta: Andi Offset.

Thamrin, A., Tantri, F. (2012). Manajemen Pemasaran. Jakarta: Rajawali Pers.

Umar, H. (2005). Studi Kelayakan Bisnis. Edisi-3. Jakarta: Gramedia Pustaka Utama. 